\title{
AbbVie buys last available priority voucher for $\$ 350$ million
}

In just over a year since the first priority review voucher (PRV) was sold for $\$ 67.5$ million, the price of vouchers has quintupled. North Chicago, Illinois-based AbbVie in August spent \$350 million on a PRV from Silver Spring, Maryland-based United Therapeutics. Because owning a PRV turns a standard, 12-month US Food and Drug Administration (FDA) review into a speedier eight-month priority review, AbbVie's transaction signals how much a fourmonth advantage is worth to a company (Nat. Biotechnol. 32, 973, 2014).

The PRV was created first as an incentive for drug makers to develop drugs for neglected tropical diseases, and later the criteria were extended to rare pediatric disease. Under the program, established by the 2007 FDA Amendments Act and the 2012 FDA Safety and Innovation Act, drug companies can earn a voucher when they gain approval for a drug against specific diseases in those areas (Nat. Biotechnol. 26, 1315-1316, 2008).

So far, the program has been successful, says Kurt Karst, an attorney with Hyman, Phelps \& McNamara in Washington, DC, who focuses on pharmaceutical regulation. One voucher, used successfully, if not dramatically by one company to leapfrog another to the finish line, clearly illustrates the vouchers' appeal. Parisbased Sanofi and Regeneron Pharmaceuticals of Tarrytown, New York, used a PRV for their proprotein convertase subtilisin kexin type-9 (PCSK9) inhibitor Praluent (alirocumab) to gain an advantage over competing PCSK9 inhibitor Repatha (evolocumab) from Thousand Oaks, California-based Amgen (Nat. Biotechnol. 33, $785-786,2015)$. The two drugs are the first entrants in a new cholesterol-lowering class that analysts expect will drive a multibillion dollar market. Sanofi and Regeneron jumped ahead of its rival using a PRV acquired in February 2014 from Novato, California-based BioMarin for $\$ 67.5$ million.

The Praluent/Repatha race highlights the circumstances that make PRV s potentially valuable. But before buying a PRV, a drug developer would need to ensure its candidate won't gain priority review on its own merits. Also, the potential market should be lucrative enough to warrant spending a few hundred million dollars on a voucher. PCSK9 blockers fit the bill.

The Praluent saga has ramped up the vouchers' market. PRVs are now seen as valuable assets, though how valuable will depend in part

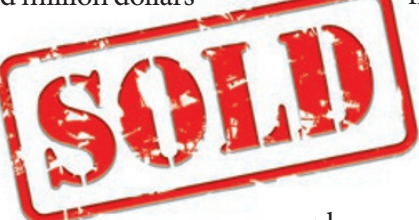

pressed time-frame for review poses a challenge, says Michael McCaughan, co-founder of Washington, DC-based healthcare policy analysis firm Prevision Policy. Companies may be using a voucher to compel the agency to "move faster on something that is already difficult for them to move fast on," he says. And right now the actual first-cycle approval performance for any application is extraordinarily high, says McCaughan. Over the past few years, $80 \%$ of drugs approved by FDA get the regulator's nod the first time around, but historically that future supply of new vouchers. Jennifer Dent, president of BIO Ventures for Global Health, a nonprofit based in Seattle, focused on health issues in developing countries, says companies working on neglected tropical diseases or pediatric indications are building the value of PRVs into their business plans. Investors are gaining confidence that neglected tropical diseases with even relatively small markets can be good bets, she says.

But Karst notes that the market for PRVs will also respond quickly to the experiences of those companies that use the existing vouchers (Table 1). "The value of these vouchers could tank if [drug sponsors] start cashing these things in and they don't produce results," he says.

From FDA's perspective, vouchers' comto treat malaria. The Swiss its own drug, the interleukin- $1 \beta$ inhibitor Ilaris (canakinumab). The company was applying to extend the indication for Ilaris from pediatric use to the broader gouty arthritis market. FDA's speedier review resulted in a speedier rejection for Novartis. Even a quicker "no" can sometimes be valuable, contends Dent, allowing companies to reallocate resources or begin collecting the necessary data to reapply to the regulator.

The agency has become considerably more nimble than it was in the past. Until 2011, a standard review resulted in a 'no' as often as it resulted in a 'yes'. Things have changed since then, but even so, for most, the real value-the one pushing up voucher prices-is connected to quicker approval. "If you have a voucher, take the money and run," says McCaughan.

Chris Morrison Yardley, Pennsylvania

Table 1 Seven PRVs awarded so far

\begin{tabular}{|c|c|c|c|c|c|}
\hline Voucher owner/location & Product approval & Voucher program & Voucher buyer(s) & Deal price, date & Voucher use and outcome \\
\hline Novartis/Basel & $\begin{array}{l}\text { Coartem (artemether and lume- } \\
\text { fantrine); approved to treat acute, } \\
\text { uncomplicated malaria, April } 2009\end{array}$ & $\begin{array}{l}\text { Neglected and } \\
\text { tropical diseases }\end{array}$ & Used by Novartis & $N / A$ & $\begin{array}{l}\text { Ilaris (canakinumab) label extension } \\
\text { to include gouty arthritis receives FDA } \\
\text { Complete Response letter, August } 2011\end{array}$ \\
\hline $\begin{array}{l}\text { Johnson \& Johnson/New } \\
\text { Brunswick, New Jersey }\end{array}$ & $\begin{array}{l}\text { Sirturo (bedaquiline) approved to } \\
\text { treat multidrug resistant pulmo- } \\
\text { nary tuberculosis, December } 2012\end{array}$ & $\begin{array}{l}\text { Neglected and } \\
\text { tropical diseases }\end{array}$ & $\mathrm{N} / \mathrm{A}$ & $\mathrm{N} / \mathrm{A}$ & Undeclared \\
\hline $\begin{array}{l}\text { BioMarin } \\
\text { Pharmaceuticals }\end{array}$ & $\begin{array}{l}\text { Vimizim (elosulfase alfa); approved } \\
\text { to treat Morquio A syndrome, } \\
\text { February } 2014\end{array}$ & Pediatric & $\begin{array}{l}\text { Sanofi and } \\
\text { Regeneron } \\
\text { Pharmaceuticals }\end{array}$ & $\begin{array}{l}\$ 67.5 \text { million, } \\
\text { July } 2014\end{array}$ & $\begin{array}{l}\text { PCSK9 inhibitor Praluent } \\
\text { (alirocumab), approved July } 2015\end{array}$ \\
\hline $\begin{array}{l}\text { Knight Therapeutics/ } \\
\text { Montreal, Quebec, } \\
\text { Canada }\end{array}$ & $\begin{array}{l}\text { Impavido (miltefosine); approved } \\
\text { to treat leishmaniasis, March } 2014\end{array}$ & $\begin{array}{l}\text { Neglected and } \\
\text { tropical diseases }\end{array}$ & Gilead Sciences & $\begin{array}{l}\$ 125 \text { million, } \\
\text { November } 2014\end{array}$ & $\begin{array}{l}\text { Single tablet HIV combination therapy } \\
\text { emtricitabine, tenofovir alafenamide, ril- } \\
\text { pivirine; submitted to FDA, July } 2015\end{array}$ \\
\hline United Therapeutics & $\begin{array}{l}\text { Unituxin (dinutuximab); approved } \\
\text { to treat high-risk neuroblastoma in } \\
\text { March } 2015\end{array}$ & Pediatric & AbbVie & $\begin{array}{l}\$ 350 \text { million, } \\
\text { August } 2015\end{array}$ & Undeclared \\
\hline $\begin{array}{l}\text { Retrophin/San } \\
\text { Diego (via Asklepion } \\
\text { Pharmaceuticals) }\end{array}$ & $\begin{array}{l}\text { Cholban (cholic acid); approved to } \\
\text { treat bile acid synthesis disorder in } \\
\text { March } 2015\end{array}$ & Pediatric & Sanofi & $\begin{array}{l}\$ 245 \text { million, } \\
\text { May } 2015\end{array}$ & Undeclared \\
\hline $\begin{array}{l}\text { Wellstat Therapeutics/ } \\
\text { Gaithersburg, Maryland }\end{array}$ & $\begin{array}{l}\text { Xuriden (uridine triacetate) } \\
\text { approved to treat hereditary orotic } \\
\text { aciduria, September } 2015\end{array}$ & Pediatric & AstraZeneca & $\begin{array}{l}\text { Undisclosed, } \\
\text { September } 2014\end{array}$ & Undeclared \\
\hline
\end{tabular}

N/A, not applicable. SOURCE: FDA; company statements 